\title{
The Figure of the Amateur for a General Organology of Sound Art Practices
}

\author{
Dr Cédric Maridet \\ Hong Kong Baptist University \\ Academy of Visual Arts \\ 5 Hereford Road, Kowloon Tong \\ Kowloon, Hong Kong SAR \\ cmaridet@hkbu.edu.hk
}

\begin{abstract}
The development of new technologies not only contributes to a new musical organology, but also drastically changes our forms of engagement with sound. A reassessed model of acoulogy informs new listening intentions through a first-person enquiry of the listening act, to define the heterogeneity of listening intentions as a way to frame the experience of sound. In this framework, composers, listeners and curators alike are defining and promoting new sound practices through heightened attention and support a process of grammatization which calls for a general organology, as defined by Bernard Stiegler. Within this theory that articulates bodily, artificial and social organs, the figure to the amateur as listener, composer or curator proves to be central. In its qualificative definition, the amateur develops particular relations with a class of object, to experiment with aesthetics technical, social, mental and corporal bodies. Drawing upon the theory of taste of Antoine Hennion, different actors can be identified in the process: the collective as a general framework, from which the definition of a particular taste can emerge; situations, or the spatio-temporal conditions that might be required for the emergence of a particular taste or experience of the object, like a specific ritual, or ways of doing things; and of course the object itself and its effects, not as being contained in the object, but as being discovered by the attention of the amateur, in a performative meaning. Within this particular setting of experimentation with this temporal object that is sound, composers, listeners and curators can engage in the different levels of Stiegler's general organology and contribute to a de-proletarianization process by creating a positive pharmakon.
\end{abstract}

listener, curator, composer, amateur, general organology, acoulogy, sound art practices, attention.

\section{INTRODUCTION}

The invention of broadcasting and recording technologies has created a new mediated experience of sound that formed the basis for new aesthetic and experimentations with new instruments like the development of acousmatic and concrete music and new forms of performances. Yet, along with new aesthetics and new practices these technical and technological apparatus have also brought particular disruptions in the forms of engagement with music and in a sensitive practice of the world. This is what Bernard Stiegler refers to as "the machinistic turn of the sensibility" (Stiegler, 2009) and it follows similar ideas developed by Bartok (Bartok, 1995) or by Barthes in Musica Practica in 1977: listening activity has been profoundly disrupted by listening technology. The sense of loss of knowledge that turned listeners mostly into cultural consumer is what Stiegler refers to as a proletarianization process. Yet, a certain usage of these particular technologies as Pierre Schaeffer's experiments, and among many others show, proves to be crucial in the explorations of ways of listening or acoulogy, following Schaeffer's neologism. A reassessed general model of acoulogy informs new listening intentions through a first- person enquiry of the listening act, to define the heterogeneity of listening intentions as a way to frame the experience of sound. In this framework, composers, listeners and curators alike are defining and promoting new sound practices through heightened attention and care. in that sense an analogy with the figure of the amateur prove to be relevant. Through a particular object-subject relationship, amateurs support a process of grammatization which calls for a general organology, as defined by Bernard Stiegler, articulating bodily, artificial and social organs.

\section{A REASSESSED GENERAL MODEL FOR ACOULOGY}

Toward the end of his Treatise Pierre Schaeffer sharpens his idea of acoulogy in relation to the different steps for musical meaning to emerge (Schaeffer, 1966). Michel Chion also explains the neologism as "the study of the potential in perceived sounds for producing distinctive characteristics which can be made into music" (Chion, 1983). While Schaeffer intends acoulogy to direct to musical sound object, Michel Chion proposes to enlarge the notion to all listening and thus detaches it from any contingency of artistic production. The object of 
acoulogy is therefore turned toward the acquisition of a particular knowledge regarding the listening activity. it advocates a phenomenological first person enquiry to look for certain features in the sound creating a framework starting at a very low cognitive level, prior to any attempt for meaning. The link with aural gestalt is here clear as there is a certain qualitative listening intention which manifest itself in the grouping of elements like unit versus whole, figure and ground. Both James Tenney and Pierre Schaeffer identify this process in their researches, yet it is important to clarify the fact that this process is experienced as imposing itself to the perceiver. The reception is passive, yet, it is not unintentional and in that sense the process can be described as automatic. When I hear a sound as an object, isolated from a ground, the perceived object is the fruit of intention, and as Michel Chion states, it is no longer the cause of my perception but its correlate (Chion, 1983). I have also explained that "this raw object is never given and is usually bound up with higher cognitive process. These higher perceptual levels are the common basis for the different listening theories" (Maridet, 2011). Acoulogy provides a powerful and meaningful framework to deal with different listening models through the concept of intentionality.

The experience of sound can be framed along several axes: the recognition or non-recognition of the source, contextualisation or decontextualisation of sound, the axis of found sound versus processed sounds, and the degree of fiction. Each of these axes can be treated in various ways, relayed and enhanced by clear choices on compositional and listening strategies to adopt, as they are used by listeners and composers alike. Moreover, defining a curator as someone who should not only take care of selection of artists and floor plans, but about the experience of the exhibition itself, as well as contextualisation through various means with the production of a particular discourse and mediation around sound, the curator might also have to compose with the cacophony of different sonorous works and might take part in the general composition and turn into a listener. To curate a sonorous exhibitions might require particular site specific adjustments and to closely work with artists. This was the underlying idea in the exhibition OOOL / sound fictions at the Mulhouse Kunsthalle in France in 2016 where the listening space of the exhibition has been composed with careful attention through a dialogue between present artists (Mathias Delplanque, Eddie Ladoire and Cedric Maridet), and curators (Anne-Laure Chamboissier and Sandrine Wymann). The result was respectful of the autonomy of every sound works, yet they would also cooperate to form a kind of collaborative composition, or constantly evolving soundtrack. The cultivation of listening and attention as acoulogy promotes prove to be essential to rediscover a sensitive practice of sound through technological mediation of experience and heightened attention. The first person reflexive approach is what led Pierre Schaeffer to come up with a systematic vocabulary and the development of a particular knowledge, not only to characterize sound objects for composing but also for analytical purposes. A particular performative and reflective activity is also central to the only fruitful definition of the figure of the amateur who is also turned toward the production of knowledge, taste, and of a savoir-faire.

\section{THE FIGURE OF THE AMATEUR}

Following the ontological development of the figure of the amateur, as developed by Jacqueline Lichtenstein, a particular definition of the one who love is relevant here. In her typology of the term amateur, she shows the evolution from a "nominative, qualifying, descriptive and evaluative" definition of the term (Lichtenstein, 2008). The qualifying term is the only focus here as it is a fruitful and positive evaluation purged from any pejorative connotations. This is also the most relevant analogy matching some characteristics of a curator. Both terms 'amateur' and 'curator' seem to connect etymologically (from Latin amore, the one who loves, and curare, to take care of), as well as historically through the idea of the status of the amateur of the Academy, a position from which art critics come as well. This specific definition of amateur refers to a particular subject-object relationship. The object is not a particular object, but a class of object, like sound works. What matters here is not a single object, but the common properties of all the objects constituting a class of objects. They constitute the founding elements of the relationship subject-object (or class of objects). Their appreciation is based on knowledge, and in that sense, the amateur is clearly a connoisseur. Bernard Stiegler recalls the emphasis of the development of knowledge through a certain form of practice through Jean Louis Jam's discussion about Count Caylus, an historical figure of amateur elected at the Academy of Painting and Sculpture (Stiegler, 2017): "for the amateur, practice is not the simple deployment of a technique and the acquirement of a know-how to match the artist, but rather the initiatory path by which, having become aware of his insufficiencies as a practitioner, he can approach the reality of a creative act and, consequently, perceive all its grandeur and mystery" (Jam, 2000). Taking the particular case of an amateur of sound, one could define a person who develops a particular attention to the common properties of all the objects constituting of the class of object sound directed to first distinction then identification of particular qualities that serves a process of discrimination of objects into a hierarchical system. These operations are both supporting knowledge and pleasure. The object and 
its effects are discovered in a performative meaning similar to what acoulogy is promoting through the assessment of listening intentions in what Pierre Schaeffer identified as the "primacy of the ear" (Schaeffer, 1957). Thus, an amateur of sound is constantly redefining and challenging his or her relation to sounds through experimentations. This is also how Antoine Hennion defines the amateur: a "virtuoso of aesthetic, technical, mental and embodied experimentation. Far from being the cultural dope evoked by Garfinkel, the great amateur... is the model of an inventive, reflective actor who is closely linked to a collective, forced to continuously challenge the determining of the effects being looked for; being from the side of the works or products, of social determinism and mimetic of tastes, of the conditioning of the mind and body, of the support on the collective, a vocabulary and social practices, and finally of the material apparatus and of the practices of access and of invented usages to intensify his or her sensations" (Hennion, 2003, my translation). In his pragmatic theory of taste Hennion emphasizes on the collective, technical and technological apparatus and corporal aspects. The amateur is then at the centre of a general organology that is rethinking the relations between biological, technical and social organs and go beyond the musicological definition of the term.

\section{TOWARDS A GENERAL ORGANOLOGY}

A general organology studies the historical and future developments of the physiological organs, artificial organs, and social organizations. Technologies of reproduction of sound have drastically change our ears, instrument to make music, from analogue to digital, and ways in which situations of listening are organized, as well as new processes of grammatisation. These organs are in a transductive relationship, as our ear and brain does not change independently from the two other organs. The amateur as being historically "a mediator, a writer, and a curator" is particularly relevant in the assemblage of the different types of organs as he is "an active participant in social circle, a producer of new practices, new discourses and artefact" (Dillet, 2017). Stiegler also emphasizes the central role of the amateur in a general organology as he mentioned that "an amateur is a psychological individual whose psychological apparatus is augmented by a critical apparatus and who is organologically equipped with practical knowledge, with an instrument, and with a social apparatus supporting the circuit of transindividuation" (Stiegler, 2017). By experimenting, multiplying the experiences with sound, the amateur actively participates in inventing new possibilities of listening, new tools, and produces long processes of transindividuation, new sensibilities and knowledge. In that sense we may say that the amateur is a pharmacological agent for what Stiegler calls deproletarianization through an attentive and careful reconnection to sensitive practices of sound and projection of possible new assemblages. The amateur is no longer a consumer of sounds but he is at the origins of possible new transindividuations, creation of knowledge, the invention of a noetic ear and new horizons of expectations.

Thus, The amateur is a multifaceted persona encompassing all kinds of listeners, composers and curators alike. Amateurs forms a collective, from which a new sense of taste, knowledge and discourses can emerge. New listening situations or particular spatio-temporal conditions in which specific listening activities may be experienced and experimented with, like new rituals or ways of doing as multiple possibilities to rediscover sensitive practice of sounds through a heightened attention and care, in a performative meaning. The primacy of the ear that is at the core of this reassessed model of acoulogy as a toolbox for amateurs, is surely here not a restrictive notion, especially when mentioning the formation of taste. The notion of aural diversity needs to be strongly put forward, as no one hears the same sound (Drever, 2019). To create a sense of a particular taste is not to close upon the binary notion of good versus bad taste but to confront oneself to sonic pluralities and alterity.

\section{REFERENCES}

Adorno, T. (1995) La Forme du Disque, Instruments, Cahiers de l'Ircam, $n^{\circ} 7$, p. 143-147.

Barthes, R. (1977) Image Music Text. Fontana, London.

Bartok, B. (1995) Musique mécanique (1937), Instruments, Cahiers de l'Ircam, n 7, p. 27-40.

Chion, M. (1983) Guide des Objets Sonores : Pierre Schaeffer et la Recherche Musicale. Buchet/Chastel: Institut National de la Communication Audiovisuelle, Paris.

Dillet, B. (2017) Proletarianization, Deproletarianization, and the Rise of the Amateur. Boundary 2, 44 (1), p. 79-105.

Drever, J. L.. (2019) 'Primacy of the Ear' - But Whose Ear?: the Case for Auraldiversity in Sonic Arts Practice and Discourse. Organised Sound, 24(1), p. 85-95.

Hennion, A. (2003) Ce que ne Disent pas les Chiffres... Vers une Pragmatique du Goût. In Donnat, Tolila (eds), Le(s) Public(s) de la Culture. 
Politiques Publiques et Equipements Culturels, Presses de Sciences Po.

Jam, J.L. (2000) Caylus, l'Amateur Crépusculaire. In Jam (ed), Les Divertissements Utiles: Des Amateurs au XVIIlè Siècle. Presses Universitaires Blaise-Pascal, Clermont-Ferrand.

Lichtenstein, J. (2008) Les Figures de l'Amateurs," L'Institut de Recherche et d'Innovation, Centre Pompidou web.iri.centrepompidou.fr /fonds/seminaires/seminaire/detail/1 (accessed April 2019)

Maridet, C. (2010) Uncured Lunatics, Sounds Are Still Bleeding. In Who Cares, 16 essays on curating in Asia, Alvaro Rodriguez Fominaya (ed.), Para/Site Art Space.

Maridet, C. (2011) Reassessment of Acoulogy for the Cultivation of Sound Practices, Proceedings of International Conference Pierre Schaeffer: mediArt, p. 75-80. Museum of Modern and Contemporary Art, Rijeka, Croatia.

Schaeffer, P. (1966) Traité des Objets Musicaux. Essai interdisciplines. Seuil, Paris.

Schaeffer, P. (1957). Vers une Musique Expérimentale. Revue musicale, No. 236. Ed. Richard-Masse, Paris.

Stiegler, B. (2006). L'Armement des Oreilles: Devenir et Avenir Industriels des Technologies de l'Écoute. Cicuit, Musiques Contemporaines, 16(3), p. 33-42.

Stiegler, B. (2009) Repenser l'Esthétique, Pour une Nouvelle Epoque du Sensible. In Trom, C. (Ed.), Esthétique et Société, Actes, L'Harmattan, Paris, p. 97-120.

Stiegler, B. (2017) The Quarrel of the Amateurs. Boundary 2, 44(1), p. 35-52.

Tenney, J. (1964). META (+) HODOS : A

Phenomenology of Twentieth-century Musical Materials and an Approach to the Study of Form. Inter-American Institute for Musical Research, Tulane University, New Orleans. 